\title{
Ciliates in ecotoxicological studies: A minireview
}

\author{
Ciliados em estudos ecotoxicológicos: uma pequena revisão
}

\author{
Jéssica Andrade Vilas-Boas ${ }^{1,2 *}$ (D), Marcus Vinicius Xavier Senra ${ }^{3}$ \\ and Roberto Júnio Pedroso Dias ${ }^{1,2}$
}

${ }^{1}$ Laboratório de Protozoologia, Laboratório Avançado de Zoologia - LAZ, Departamento de Zoologia, Universidade Federal de Juiz de Fora - UFJF, Rua José Lourenço Kelmer, s/n, CEP: 36036-900, Juiz de Fora, MG, Brasil

${ }^{2}$ Programa de Pós-graduação em Ecologia - PGECOL, Universidade Federal de Juiz de Fora UFJF, Rua José Lourenço Kelmer, s/n, CEP: 36036-900, Juiz de Fora, MG, Brasil

${ }^{3}$ Programa de Pós-graduaçáo em Meio Ambiente e Recursos Hídricos, Instituto de Recursos Naturais, Universidade Federal de Itajubá - UNIFEI, Av. BPS, 1303, Pinheirinho, CEP: 37500-903, Itajubá, MG, Brasil

*e-mail: jessica_biol@outlook.com

Cite as: Vilas-Boas, J.A., Senra, M.V.X. and Dias, R.J.P. Ciliates in ecotoxicological studies: a minireview. Acta Limnologica Brasiliensia, 2020, vol. 32, e202.

Abstract: The present study has conducted a minireview of ecotoxicological studies using ciliated microeucaryotes, presenting a breif history, describing the current scenario and pointing out their methodological approaches gaps. We highlight in a clear and objective way the ecological importance of ciliates for ecosystems, their usefulness and the inherent characteristics that classify them as a good model organism. Finally, we discuss some modern tools that can be added to studies with ciliates in the near future.

Keywords: Ciliophora, ecotoxicology; model organism.

Resumo: $\mathrm{O}$ presente estudo realizou uma pequena revisão de estudos ecotoxicológicos utilizando microeucariotos ciliados, apresentando um histórico, descrevendo o cenário atual e apontando suas lacunas nas abordagens metodológicas. Destacamos de forma clara e objetiva a importância ecológica dos ciliados para os ecossistemas, sua utilidade e as características inerentes que os classificam como bons organismos modelo. Finalmente, discutimos algumas ferramentas modernas que podem ser adicionadas aos estudos com os ciliados em um futuro próximo.

Palavras-chave: Ciliophora, ecotoxicologia; organismo modelo. 


\section{Introduction}

Despite all the importance of water for mankind, the acelerated deterioration of aquatic systems has been observed all over the world, affecting human health and the environment (Schwarzenbach et al., 2010). The population increase, occupation of irregular areas, agriculture, discard of industrial and urban effluents, mining and landfill activities, fragmentation of the landscape, deviation of rivers and the load of contaminants from different sources has been causing, unfortunately, huge and unprecedented impacts on aquatic ecosystems causing changes in the chemical profile of waterbodies (Molden et al., 2007). According to the Chemical Abstracts Registry database (www.cas.org) there are more than 100 million chemical substances and less than $0.36 \%$ are regularized. These chemicals can reach both surface and subterranean water bodies even those in far remote areas (Bernhardt et al., 2017). This represents a human health concerned, because many of these substances can be toxic, reducing the availability of potable water (Oki \& Kanae, 2006; UNESCO, 2009). In fact, it is estimated that by $2025,50 \%$ of the population will live in countries with water shortages (Qureshi \& Hanjra, 2010).

Accordingly, the best way to ensure the quality of water resources is through the establishment of accurate standard protocols, management methods and environmental legislation, which would provide also the guidelines for proper environmental monitoring (Schwarzenbach et al., 2006; Schwarzenbach et al., 2010). The degree of contamination of aquatic environments is evaluated mainly through chemical analysis and biomonitoring programs (USEPA, 1992; Silveira, 2004). However, these approaches are not enough to water quality control and must be complemented by ecotoxicological studies, which are useful for assessing the ability of a toxic agent to produce effects on organisms (Forget et al., 2000).

Ecotoxicology is used to integrate and understand the harmful effects of chemical substances on populations, communities, and ecosystems (Walker et al., 1996; Forbes \& Forbes, 1994), and this knowledge can be used to complement environmental impact studies and on risk assessment programs (Silva et al., 2015). One of the most important steps for ecotoxicological studies is to find a model organism which is ideal and able to provide reproducible information on the acute and chronic toxicity of pollutants in aquatic environments. Some good examples of model organisms (i.e. Pseudokiriella subcaptata, Daphnia similis, Ceriodaphnia spp. and Danio rerio) are representatives of different trophic levels and are useful for answering different questions. This representativeness allows a better understanding of the effects caused by toxic agents and contributes to the establishment of toxicity threshold values (Grolière et al., 1990; Lombardi, 2004).

The choice of a model organism should be based on previous knowledge of their biology, physiology, behavior, and food habits; they need to be abundant and available; have ecological representativeness within the ecosystem; have constant and accurate sensitivity; short life cycle; commercial importance and; be easily cultivated and maintained in the laboratory (Niemeyer et al., 2010).

Ciliated microeukaryotes have been used in ecotoxicological studies since the 1950s (Grebecki $\&$ Kuznicki, 1956). However, these organisms have been historically neglected in detriment of other model organisms (Figure 1). Many ciliate species, such as from genera Paramecium and Tetrahymena have many biological features that makes them appropriate to toxicity bioassays, such as the presence of a delicate cell membrane, small size (from $-10 \mu \mathrm{m}$ to $4,500 \mu \mathrm{m}$ ), which allows the use of reduced volumes for maintenance and experimentation, short life cycle and high reproductive rate, allowing for long-term transgenerational assays in relatively short time periods. Also, encystement stages allow greater resistance to environmental stressors and allow the measuring the possible effects of toxic substances (Soldo \& Van Wagtendonk, 1969; Lee \& Soldo, 1992; Nerad \& Daggett, 1992; Madoni et al., 1996; Gilron \& Lynn, 1998; Madoni, 2000, 2003, 2011; Gutierrez et al., 2003; Delmonte Corrado et al., 2005; Kchaou et al., 2009; Gomiero et al., 2013).

The phylum Ciliophora represents a basic component of microplankton and microbenthic

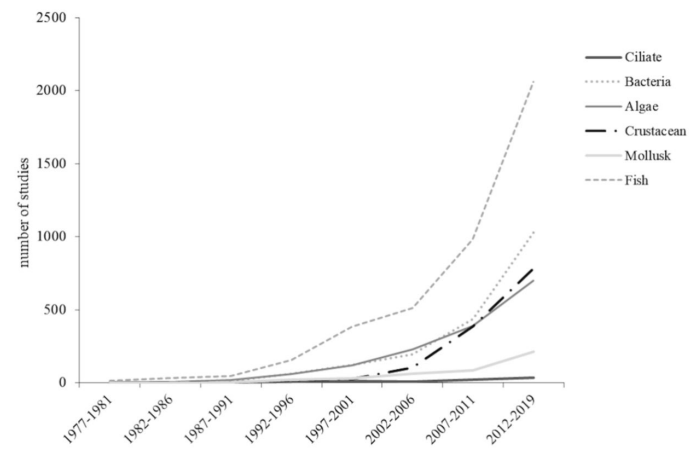

Figure 1. Number of ecotoxicological studies per model organism. Data available in the Scopus database from 1977 to 2019 (survey conducted 06/06/2019). Codes used to search: Ecotoxicol * AND ciliate *, Ecotoxicol * AND algae *, Ecotoxicol * AND bacteria *, Ecotoxicol * AND mollusk *, Ecotoxicol * AND crustacean * AND Ecotoxicol * AND fish * 
within environments (Finlay \& Fenchel, 1996; Madoni, 2000). They have a wide geographical distribution and can be found in freshwater, brackish, salty, bromeliads and edaphic environments, such as superficial soils, mosses and lichens (Puytorac, 1994; Corliss, 1979; Joppert et al., 1995; Foissner et al., 2002; Foissner, 2003; Lynn, 2008). Ciliates are mostly heterotrophic organisms, predators of bacteria and other protozoa (Fenchel, 1987; Beaver \& Crisman, 1989; Müller et al., 1991), and are preyed by different species from the zooplankton. Therefore, representing an essential link for the flow of carbon and energy to higher trophic levels (Fenchel, 1987; Sherr \& Sherr, 1994; Madoni, 2000).

The presence of ciliates in several habitats is influenced by their tolerance and adaptability to the different physical and chemical conditions of the environments (Noland, 1925; Sleigh, 1988). When under unfavorable conditions, they form resistance cysts, which can be dispersed and transported by wind, water, insects, among other animals (Finlay \& Fenchel, 1996; Finlay, 2002; Esteban \& Finlay, 2003; Fenchel \& Finlay, 2004). This adaptive changes may be linked to the specificity of the recurrent changes in the physical-chemical factors of the water, such as temperature, amount of dissolved organic matter, $\mathrm{pH}$, conductivity and oxygen concentration (Noland, 1925; Kudo, 1966; Sleigh, 1988; Madoni, 2005; Madoni \& Barghiroli, 2007). Seasonal, vertical, trophic and flood pulse variations can also be determining factors in the patterns of distribution, composition and abundance of ciliates in aquatic systems (Madoni, 2003, 2005; Velho et al., 2005, 2013; Gomiero et al., 2013; Debastiani et al., 2016; Pauleto et al., 2009).

Ciliates can be used as bioindicators of water quality in biomonitoring studies (Madoni, 1994, 2003, 2005; Dias et al., 2008; Bagantini et al., 2013; Debastiani et al., 2016). They play an important role in the purification process in water treatment plants, especially in the activated sludge system, where it makes up more than $9 \%$ of the biomass of microorganisms (Madoni, 1994, 2003, 2011).

The use of ciliates as model organisms had its beginning with the work of Gause (1934) in population ecology. The Russian ecologist used the ciliate species Paramecium caudatum and Paramecium aurelia to test the hypothesis of competitive exclusion. The results showed that both species of ciliates occupy the same ecological niche and can not coexist. Since then, the use of these organisms as models for applied studies has been through the knowledge of the species through the use of techniques of optical microscopy and appropriate techniques (Klein, 1958; Foissner, 1994, 1999; Dieckmann, 1995; Kapuscinski, 1995; Foissner \& Berger, 1996; Finlay \& Fenchel,
1999; Lynn, 2008; Mitchell \& Meisterfeld, 2005). Biology information (Lynn, 2008; Lynn \& Small, 2002; Pratt \& Cairns Júnior, 1985; Weisse, 2017), evolution and taxonomy (Foissner \& Berger, 1996; Lynn, 2008; Gao et al., 2016), behavioral traits (Nishigami et al., 2018; Ohmura et al., 2018; Ishikawa, 2019), physiology, histology and even the genome description of the species, i.e., Tetrahymena thermophila, Paramecium tetraurelia, Euplotes crassus, Oxytrich trifallax and Stentor coeruleus (Aury et al., 2006; Eisen et al., 2006; Vinogradov et al., 2012; Swart et al., 2013; Slabodnick et al., 2017) may be useful for answering different questions within ecotoxicology. Therefore, the present study presents a minireview of the ecotoxicological studies with ciliates, the importance of these organisms for the aquatic ecosystems, the approaches and gaps found, besides presenting some perspectives for the advancement of the studies in the near future.

\section{Ciliates as Models in Ecotoxicological Studies}

\subsection{Brief history and approaches}

The first ecotoxicological stuty using ciliates was published in the 1950s (Grebecki \& Kuznicki, 1956). Paramecium caudatum species were exposed to different concentrations of Copper, Mercury, Cadmium, Zinc, Nickel, Cobalt, and Chromium. Posteriorly, some studies were done using different ciliate species and approach (Figure 2A, Supplementary Material Table S1). The main ecotoxicological approaches using ciliated organisms are those related to the determination of lethal concentrations, changes in behavioral, substances accumulation and morphological changes (Figure 2B). Acute and chronic tests have been used since the first works to identify the maximum concentration ranges that cause population to decline and/or mortality (mean lethal concentration - $\mathrm{LC}_{50}$ ), to check cell deformities, heavy metal accumulation and/or behavioral changes. Mortality and/or survive states are commonly established through optical microscope (Madoni, 1994; Madoni et al., 1992, 1996; Madoni \& Romeo, 2006; Mansano et al., 2016). Moreover, microscopy can also be used to evaluate other features such as behavior, morphological deformities, changes in generation time, abundance and cell shape. Rao et al. (2006) observed changes in cell shape, developing irregular membrane bubbles promoting cell lysis. In addition, a tracking system with optical microscope was used to observe changes in the locomotion of Paramecium caudatum. An initial increase and subsequent decrease in swimming speed were observed when exposed to concentrations of an acephate insecticide. The number of generations decreased and the generation time increased significantly in a manner 

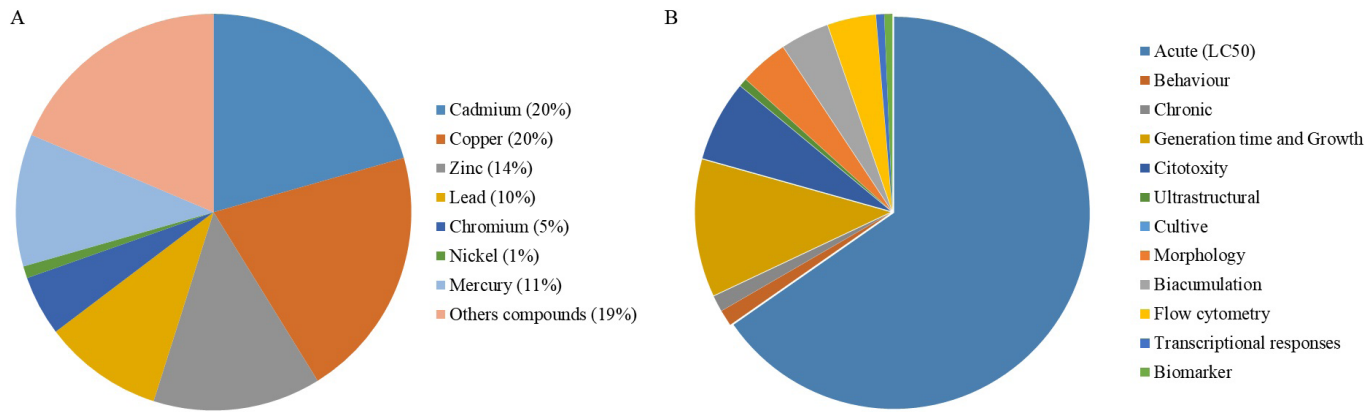

Figure 2. $A=$ Percentage of ecotoxicological studies per compound; $B=$ Endpoints distributions.

dependent on the sublethal concentrations used. Changes in the number and ultrastructure of cilia were observed in the study by Li et al. (2016) in the exposure of an emerging compound (Tris (1,3-dichloro-2propyl) phosphate (TDCIPP). The authors conclude by highlighting that the results suggest that chemical exposure in organisms of the early trophic levels can cause long-term damage. The resistance of ciliates to metal ions shows the importance of these organisms for bioremediation in industrial wastewater (Madoni, 1994; Martin-Gonzalez et al., 2006; Rehman et al., 2009; Chaudhry \& Shakoori, 2011; Elguero et al., 2019).

Rico et al. (2009) evaluated the induction of reactive oxygen species (ROS) after exposure to heavy metals in ciliates. Benbouzid et al. (2012) observed reduced growth, increased generation time, respiratory metabolism disturbance (significant increase in oxygen uptake), and high percentage response in a ciliate species in a short-term $(24 \mathrm{~h})$ experiment. Kim et al. (2014) measured intracellular oxygen levels (ROS) and total glutathione content (GSH) using gene expression by means of RT-PCR. Wu et al. (2015) used UV spectrophotometry to visualize changes in enzymatic antioxidants in a ciliate species. The application of modern techniques may be useful for ecotoxicological studies with ciliates, such as the use of flow cytometry by Liu et al. (2017) to evaluate the Mercury accumulation properties in species of the genus Tetrahymena.

The use of the 'Omics' in ecological studies has allowed advances and brought the possibility of evaluating changes in different levels of cellular organization, such as individual, tissue, cell and molecule (Zhang et al., 2018). The union of these sciences allows the uncovering of cellular processes details of many organisms, such as the screening of genes whose loss of function may confer resistance or sensitivity to phenotypic toxicity, such as programmed cell death (Jo et al., 2009). In the study by Kim et al. (2018) it was possible to evaluate the transcriptional response of the antioxidant defense system and heat shock protein of the Euplotes crassus species. The production of proteins or metabolites for the formulation of vaccines and drugs has also been performed from the use of ciliates (Putten et al., 2006, Hartmann et al., 2000). The successes of studies like these require the use of organisms that are culturable under laboratory/industrial conditions such as ciliates. In this sense, there are a lot of tools that can be used to evaluate environmental alteration using ciliates in different approaches contributing to the understanding of how environmental changes can affect the role of these organisms in the ecosystem processes.

\subsection{Species}

In regards to ciliates species, more than 50 have been used in ecotoxicological studies to evaluate the impact of different compounds (Table S1). In this sense, given its wide geographic distribution and short cell cycles, Paramecium caudatum could be considered a good model for behavioral and population reproductive rate studies allowing evaluation of a large number of generations in short time spans (Rao et al., 2006; Mansano et al., 2016). While T. thermophila, Paramecium tetraurelia (and also P. caudatum), Euplotes crassus, Oxytrich a trifallax and Stentor coeruleus can be considered are potential model species in molecular (ecotoxicogenomics) approaches, given the availability of their genome in sequence databases (Aury et al., 2006; Eisen et al., 2006; Vinogradov et al., 2012; Swart et al., 2013; Slabodnick et al., 2017).

The intensification in the use of ciliated protists will be of great value to the field of ecotoxicological. They present several characteristics that make them model organisms (Giovanni Junior \& Carvalho, 2017) and since many species are aquatic, their use can contribute to more accurately evaluate the changes these environments have been facing, as consequence of antropic activites.

\subsection{Substances}

As available within the AQUIRE database (USEPA, 2019), the heavy metals were the first and the most often chemicals used in ecotoxicological studies using ciliates as model organisms (Figures 2A, 3 and 4). However, over the time, the environmental impact of contaminants 


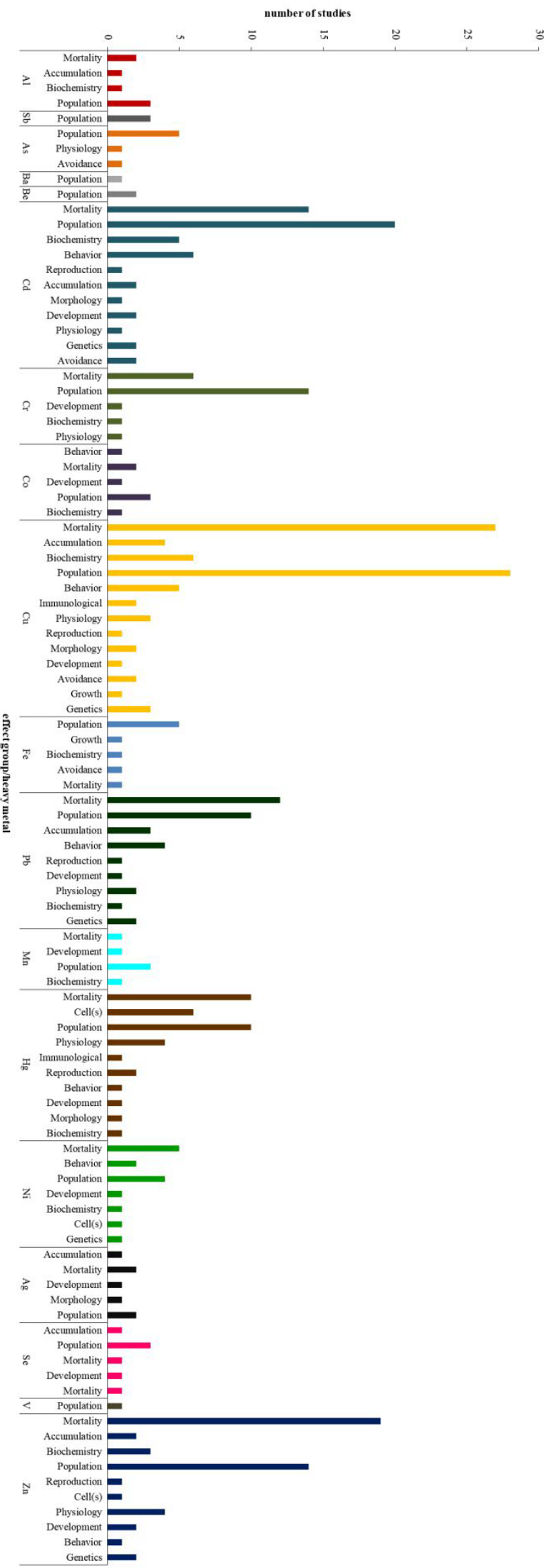

Figure 3. Number of studies with heavy metals and their respective approaches according to the Ecotox knowledgebase database (USEPA, 2019) (survey conducted on 05/28/2019); Number of studies with heavy metals and their respective approaches according to the Ecotox knowledgebase database (USEPA, 2019) (survey conducted on 05/28/2019). 


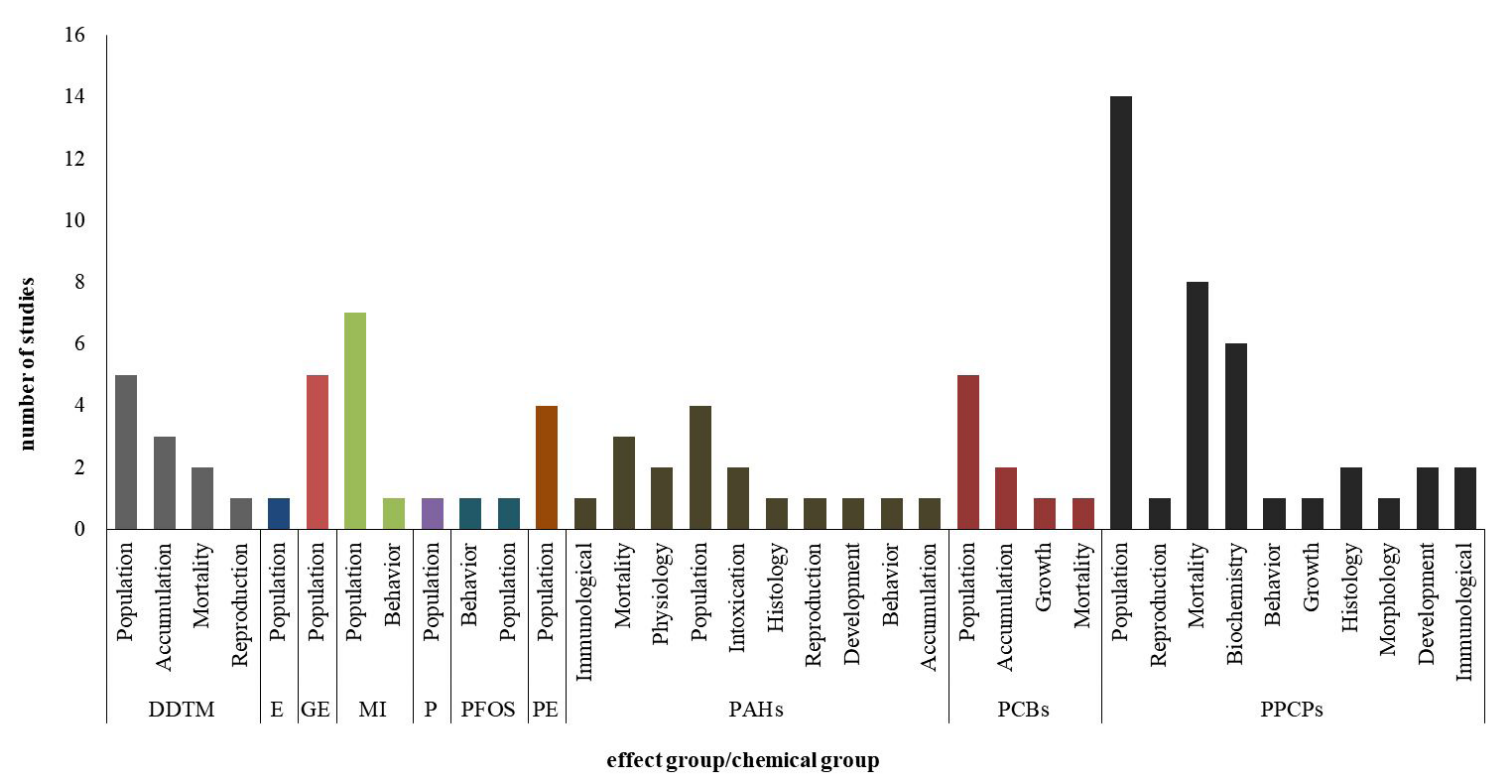

Figure 4. Number of studies with organic compounds and their respective approaches according to the Ecotox knowledgebase database (USEPA, 2019) (survey conducted on 05/28/2019); DDTM: DDT and metabolites, E: Explosives; GE: Glycol ethers, MI: Major ions, P: Perchlorates, PFOS: Perfluorooctane sulfonates and acids, PE: Phthalate Esters, PAHs: Polyaromatic Hydrocarbons, PBCs: Polychlorinated Biphenyls, PPCPs: Pharmaceutical Personal Care Products.

of emerging concerns, such as inorganic, organic, $\beta$-blockers, herbicides, insecticides and pesticides started to have their toxicity evaluated also within ciliate species (Figures 2A, 3 and 4). Among heavy metals, Copper, Cadmium, Zinc, Lead and Mercury were the most frequently used in ciliates and within these, the assays directed toward their effects over populations (growth rate), mortality (lethal concentration) and accumulation were the most often used (Figures 2A, 3 and 4). With regards to contaminants of emergent concern, the personal pharmaceutical care products (PPCPs) were the most often used compounds against ciliates, followed by polycyclic aromatic hydrocarbons, in mortality and populational alteration assays (Figures 2A, 3 and 4).

\subsection{Methodological approaches gaps}

There are numerous growth media and conditions available in the literature for in vitro maintenance of ciliates in laboratory. For example, species of the genus Tetrahymena can be cultivated in axenic cultures based on protease (Carter \& Cameron, 1973; Schlenk \& Moore, 1994; Gallego et al., 2007; Zhang et al., 2013, Liu et al., 2017). Paramecium and many others can grow using the Cerophyl culture medium proposed by Sonnebobn (1970) was used by Joshi \& Misra (1986), Juchelka \& Snell (1994), Pratt et al. (1997) and Salvadó et al. (1997). Mineral water and bark rice, is a common general used media used to promote the growth of bacteria that are, actualy the sources of food for ciliates employed by Ruthven \& Cairns Junior (1973), Dive et al. (1980), Madoni et al.(1992), Madoni (1994, 2000), Madoni \& Romeo (2006), Wanick et al. (2008) and Bitencourt et al. (2016). Water from the original sample sites are used in association with a variety of cereals as in the studies of Nalecz-Jawecki et al. (1993), Madoni et al. (1996), Rehman et al. (2005, 2006, 2007, 2007a, 2008, 2008a, 2009, 2010, 2010a) and Shakoori et al. (2011). There are also culture media available for marine ciliates, such as proposed by Yoo \& Hur (2002) and used by Kim et al. (2011, 2014, 2018). On the other hand, Madoni et al. (1996) did not use methods of cultivation in laboratory. The species used in the bioassays were directly from activated sludge. Twagilimana et al. (1998) tested different culture conditions for the Spirostomum ambiguum species. The authors conclude by highlighting the need for reproducibility of the assays in order to allow comparison between laboratories.

The major challenge today limiting the use of ciliates in ecotoxicological tests is the creation of a standard methods. Thus, it is necessary to develop specific methods to each potential species leading to efficient, replicable and comparable bioassays. The standardization of procedures in toxicity tests is paramount for the reproducibility and 
comparability of results comparability of results from laboratories in different geographical regions (Soares \& Calow, 1993). Furthermore, they can help environmental managers since one of the first approaches in environmental studies is precisely the ecotoxicological risk assessment, which is responsible for showing the fate and effects of chemicals in the environment (Vindimian, 2001).

\section{Final Considerations}

Here, we highlighted the advantages of using ciliates in ecotoxicological studies. They have many characteristics that make them good model organisms for environmental toxicity evaluation. Therefore, they can potentially contribute to the establishment of more accurate guidelines and risk management programs, and also represent a valuable system to study how environmental contaminants may impacts normal cell biological functions. For these reasons, we hope that in a near future more ecotoxicological works will be using ciliates as model organisms.

\section{Acknowledgements}

The authors acknowledge the "Coordenação de Aperfeiçoamento de Pessoal de Nível Superior" (CAPES) for the post-doctoral (PNPD) and PhD fellowship confered to MS and JAVB, respectively. This work was granted by the "Fundação de Amparo à Pesquisa do Estado de Minas Gerais" (FAPEMIG, CRA 03648/16) and "Conselho Nacional de Desenvolvimento Científico e Tecnológico" (CNPq, Bolsa de Produtividade to RJPD).

\section{References}

AURY, J.M., JAILLON, O., DURET, L., NOEL, B., JUBIN, C., PORCEL, B.M., SÉGURENS, B., DAUBIN, V., ANTHOUARD, V., AIACH, N., ARNAIZ, O., BILLAUT, A., BEISSON, J., BLANC, I., BOUHOUCHE, K., CÂMARA, F., DUHARCOURT, S., GUIGO, R., GOGENDEAU, D., KATINKA, M., KELLER, A.M., KISSMEHL, R., KLOTZ, C., KOLL, F., LE MOUËL, A., LEPÈRE, G., MALINSKY, S., NOWACKI, M., NOWAK, J.K., PLATTNER, H., POULAIN, J., RUIZ, F., SERRANO, V., ZAGULSKI, M., DESSEN, P., BÉTERMIER, M., WEISSENBACH, J., SCARPELLI, C., SCHÄCHTER, V., SPERLING, L., MEYER, E., COHEN, J. and WINCKER, P. Global trends of whole-genome duplications revealed by the ciliate Paramecium tetraurelia. Nature, 2006, 444(7116), 171-178. http://dx.doi.org/10.1038/ nature05230. PMid:17086204.
BAGANTINI, I.L., SPÍNOLA, A.L.G., PERES, B.M., MANSANO, A.S., RODRIGUES, M.A.A., BATALHA, M.A.P., LUCCA, J.V., GODINHO, M.J.L., TUNDISI, T.M. and REGALI-SELEGHIM, M.H. Protozooplankton and its relationship with environmental conditions in 13 water bodies of the Mogi-Guaçu basin - SP, Brazil. Biota Neotropica, 2013, 13, 1-12.

BEAVER, J. and CRISMAN, T.L.R. The role of Ciliated Protozoa in pelagic freshwater ecosystems. Microbial Ecology, 1989, 17(2), 111-136. http://dx.doi. org/10.1007/BF02011847. PMid:24197241.

BENBOUZID, H., BERREBBAH, H., BERREDJEM, M. and DJEBAR, M.R. Toxic effects of phosphoramidate on Paramecium sp. with special emphasis on respiratory metabolism, growth, and generation time. Toxicological and Environmental Chemistry, 2012, 94(3), 557-565. http://dx.doi.org /10.1080/02772248.2012.655696.

BERNHARDT, E.S., ROSI-MARSHALL, E.J. and GESSNER, M.O. Synthetic chemicals as agents of global change. Frontiers in Ecology and the Environment, 2017, 5(2), 84-89. http://dx.doi. org/10.1002/fee. 1450

BITENCOURT, J.A.P., PEREIRA, D.C., SILVANETO, I.D., CRAPES, M.C.C. and NETO, J.A.B. Evaluation of sensitivity to zinc and copper of Diophrys appendiculata (Protozoa, Ciliophora) and their associated bacteria, both isolated from a tropical polluted bay. Revista Brasileira de Zoociências, 2016, 17(1), 112-123.

CARTER, J.W. and CAMERON, I. Toxicity bioassay of heavy metals in water using Tetrahymena pyriformis. Water Research, 1973, 7(7), 951-961. http://dx.doi org/10.1016/0043-1354(73)90177-2.

CHAUDHRY, R. and SHAKOORI, A.R. Characterization of copper resistant ciliates: Potential candidates for consortia of organisms used in bioremediation of wastewater. African Journal of Biotechnology, 2011, 10(45), 9101-9113. http:// dx.doi.org/10.5897/AJB10.2405.

CORLISS, J.O. The ciliated protozoa. London: Pergamon Press, 1979, $455 \mathrm{p}$.

DEBASTIANI, C., MEIRA, B.R., LANSAC-TÔHA, F.M., VELHO, L.F.M. and LANSAC-TÔHA, F.A. Protozoa ciliates community structure in urban streams and their environmental use as indicators. Brazilian Journal of Biology $=$ Revista Brasileira de Biologia, 2016, 76(4), 1043-1053. http://dx.doi. org/10.1590/1519-6984.08615. PMid:27191462.

DELMONTE CORRADO, M.U., TRIELLI, F., AMAROLI, A., OGNIBENE, M. and FALUGI, C. Protists as tools for environmental biomonitoring: importance of cholinesterase enzyme activities. In: A.R. BURK, ed. Water pollution. Nova Iorque: Nova Science Publishers, 2005, pp. 181-200. 
DIAS, R.J.P., WIELOCH, A.H.B. and D'AGOSTO, M.A. The influence of environmental characteristics on the distribution of ciliates (Protozoa, Ciliophora) in an urban stream of southeast. Brazilian Journal of Biology = Revista Brasileira de Biologia, 2008, 68(2), 287-295. http://dx.doi.org/10.1590/S151969842008000200009 . PMid:18660956.

DIECKMANN, J. An improved protargol impregnation for ciliates yielding reproducible results). European Journal of Protistology, 1995, 31(4), 372-382. http:// dx.doi.org/10.1016/S0932-4739(11)80449-9.

Dive, D., LECLERC, H. and PERSOONE, G. Pesticide toxicity on the ciliate protozoan Colpidium campylum: possible consequences of the effect of pesticides in the aquatic environment. Ecotoxicology and Environmental Safety, 1980, 4(2), 129-133. http://dx.doi.org/10.1016/0147-6513(80)90014-7. PMid:7389633.

EISEN, J.A., COYNE, R.S., WU, M., WU, D., THIAGARAJAN, M., WORTMAN, J.R., BADGER, J.H., REN, Q., AMEDEO, P., JONES, K.M., TALLON, L.J., DELCHER, A.L., SALZBERG, S.L., SILVA, J.C., HAAS, B.J., MAJOROS, W.H., FARZAD, M., CARLTON, J.M., SMITH JUNIOR, R.K.J.R., GARG, J., PEARLMAN, R.E., KARRER, K.M., SUN, L., MANNING, G., ELDE, N.C., TURKEWITZ, A.P., ASAI, D.J., WILKES, D.E., WANG, Y., CAI, H., COLLINS, K., STEWART, B.A., LEE, S.R., WILAMOWSKA, K., WEINBERG, Z., RUZZO, W.L., WLOGA, D., GAERTIG, J., FRANKEL, J., TSAO, C.C., GOROVSKY, M.A., KEELING, P.J., WALLER, R.F., PATRON, N.J., CHERRY, J.M., STOVER, N.A., KRIEGER, C.J., DEL TORO, C., RYDER, H.F., WILLIAMSON, S.C., BARBEAU, R.A., HAMILTON, E.P. and ORIAS, E. Macronuclear genome sequence of the ciliate Tetrahymena thermophila, a model eukaryote. PLoS Biology, 2006, 4(9), e286. http://dx.doi.org/10.1371/ journal.pbio.0040286. PMid:16933976.

ELGUERO, M.E., NUDEL, C.B. and NUSBLAT, A.D. Biotechnology in ciliates: An overview. Critical Reviews in Biotechnology, 2019, 39(2), 220-234. http://dx.doi.org/10.1080/07388551.2018.15301 88. PMid:30422738.

ESTEBAN, G.F. and FINLAY, B.J. Cryptic freshwater ciliates in a hypersaline lagoon. Protistology, 2003, 154(3-4), 411-418. http:// dx.doi.org/10.1078/143446103322454149. PMid:14658497.

FENCHEL, T. and FINLAY, B.J. The ubiquity of small species: Patterns of local and global diversity. Bioscience, 2004, 54(8), 777-784. http://dx.doi. org/10.1641/0006-3568(2004)054[0777:TUOSS P]2.0.CO;2.
FENCHEL, T. The Ecology of the Protozoa: The biology of free-living phagotrophic protists. New York: Springer Verlag, 1987.

FINLAY, B. and FENCHEL, T.J. Divergent perspectives on protist species richness. Protistology, 1999, 150(3), 229-233. http://dx.doi.org/10.1016/S14344610(99)70025-8. PMid:10575696.

FINLAY, B.J. and FENCHEL, T. Ecology: role of ciliates in the natural environment, In: K. HAUSMANN and P.C. RADBURY, eds. Ciliates: cells as organisms. Stuttgart: Fischer Verlag, 1996, pp. 417-440.

FINLAY, B.J. Outing the researcher: The provenance, principles and practice of reflexivity. Qualitative Health Research, 2002, 12(4), 531-545. http:// dx.doi.org/10.1177/104973202129120052. PMid:11939252.

FOISSNER, W. and BERGER, H. A user-friendly guide to ciliates (Protozoa, Ciliophora) commonly used by hydrobiologists as bioindicators in rivers, lakes, and waste waters, with notes on their ecology. Freshwater Biology, 1996, 35, 375-498.

FOISSNER, W. Morphology and morphogenesis of Circinella arenicolanov. gen., nov. spec., a cephalized hypotrich (Ciliophora, Hypotrichida) from sand dunes in Utah, USA. European Journal of Protistology, 1994, 30(2), 156-170. http://dx.doi.org/10.1016/ S0932-4739(11)80026-X.

FOISSNER, W. Morphology and ontogenesis of Bromeliophyra brasiliensis gen. n., sp. n., a new tetrahymenid ciliate (Protozoa: Ciliophora) from Brazilian tank bromeliads (Bromeliaceae). Acta Protozoologica, 2003, 42, 55-70.

FOISSNER, W. Protist diversity: Estimates of the nearimponderable. Protistology, 1999, 150(4), 363-368. http://dx.doi.org/10.1016/S1434-4610(99)70037-4. PMid:10714770.

FOISSNER, W., AGATHA, S. and BERGER, H. Soil ciliates (Protozoa, Ciliophora) from Namibia (Southwest Africa), with emphasis on two contrasting environments, the Etosha Region and the Namib Desert. Denisia, 2002, 5, 1-1459.

FORBES, V.E. and FORBES, T.L. Ecotoxicology in theory and practice. 1st ed. London: Chapman and Hall Ecotoxicology, 1994. Series 2.

FORGET, G., GAGNON, P., SANCHEZ, W.A. and DUTKA, B.J. Overview of methods and results of the eight countries international development research centre (IDRC) water tox project. Environmental Toxicology, 2000, 15(4), 264-276. http://dx.doi. org/10.1002/1522-7278(2000)15:4<264::AID-

TOX2>3.0.CO;2-Q.

GALLEGO, A., MARTÍN-GONZÁLEZ, A., ORTEGA, R. and GUTIÉRREZ, J. Flow cytometry assessment of cytotoxicity and reactive oxygen species generation by single and binary mixtures of cadmium, zinc and copper on populations of the ciliated protozoan 
Tetrahymena thermophila. Chemosphere, 2007, 68(4), 647-661. http://dx.doi.org/10.1016/j. chemosphere.2007.02.031. PMid:17397902.

GAO, F., WARREN, A., ZHANG, Q., GONG, J., MIAO, M., SUN, P., XU, D., HUANG, J., YI, Z. and SONG, W. The all-data-based evolutionary hypothesis of ciliated protists with a revised classification of the Phylum Ciliophora (Eukaryota, Alveolata). Nature. Scientific Reports, 2016, 29(6), $1-14$.

GAUSE, G.F. The Struggle For Existence. 1st ed. Baltimore: Williams \& Wilkins, 1934. Archived from the originalon 2016-11-28. Retrieved 2016-11-24.

GILRON, D.L. and LYNN, D.H. Ciliated protozoa as test organism in toxicity assessment. In: P.G. WELLS, K. LEE and C. BLAISE, ed. Microscale testing in aquatic toxicology. Boca Raton: CRC Press, 1998, pp. 323-336.

GIOVANNI JUNIOR, N. and CARVALHO, M.B. A utilização de protozoários como organismos bioindicadores em ensaios ecotoxicológicos e suas respostas à exposição a fármacos e outros compostos. Periódico Eletrônico Fórum Ambiental da Alta Paulista, 2017, 13(4), 24-37.

GOMiero, A., DAGNino, A., NASCi, C. and VIARENGO, A. The use of protozoa in ecotoxicology: Application of multiple endpoint tests of the ciliate $E$. crassus for the evaluation of sediment quality in coastal marine ecosystems. The Science of the Total Environment, 2013, 442, 534-544. http://dx.doi.org/10.1016/j.scitotenv.2012.10.023. PMid:23202299.

GREBECKI, A. and KUZNICKI, L. Autoprotection in Paramecium caudatum by influencing the chemical properties of its medium. Acta Biologiae Experimentalis, 1956, 17, 71-107.

GROLIÈRE, C.A., CHAKLI, R., SPARAGANO, O. and PEPIN, D. Application de la colonisation d'un substrat artificiel par les ciliés à l'étude de la qualité des eaux d'une riviére. European Journal of Protistology, 1990, 25(4), 381-390. http://dx.doi.org/10.1016/ S0932-4739(11)80131-8. PMid:23196052.

GUTIÉRREZ, J.C., MARTÍN-GONZÁLEZ, A., DÍAZ, S. and ORTEGA, R. Ciliates as a potential source of cellular and molecular biomarkers/ biosensors for heavy metal pollution. European Journal of Protistology, 2003, 39(4), 461-467. http:// dx.doi.org/10.1078/0932-4739-00021.

HARTMANN, M., GUBERMAN, A., FLORINCHRISTENSEN, M. and TIEDTKE, A. Screening for and characterization of phospholipase A1 hypersecretory mutants of Tetrahymena thermophila. Applied Microbiology and Biotechnology, 2000, 54(3), 390-396. http://dx.doi.org/10.1007/ s002530000405. PMid:11030577.
ISHIKAWA, T. Swimming of ciliates under geometric constraints. Journal of Applied Physics, 2019, 125(20), 1-10. http://dx.doi.org/10.1063/1.5084764.

JO, W.J., LOGUINOV, A., WINTZ, H., CHANG, M., SMITH, A.H., KALMAN, D., ZHANG, L., SMITH, M.T. and VULPE, C.D. Comparative functional genomic analysis identifies distinct and overlapping sets of genes required for resistance to monomethylarsonous acid (MMAIII) and arsenite (AsIII) in yeast. Toxicological Sciences, 2009, 111(2), 424-436. http://dx.doi.org/10.1093/toxsci/kfp162. PMid:19635755.

JOPPERT, F., GUEDES, L.H.C. and SILVA-NETO, I.D. Qualitative study of the ciliated protozoa in tanks of Aechmea nudicalis (Bromeliaceae) at Barra de Maricá, Rio de Janeiro. Memorias do Instituto Oswaldo Cruz, 1995, 90, 251.

JOSHI, P.C. and MISRA, R.B. Evaluation of chemically-induced phototoxicity to aquatic organism using Paramecium as a model. Biochemical and Biophysical Research Communications, 1986, 139(29), 79-84. http://dx.doi.org/10.1016/S0006291X(86)80082-1.

JUCHELKA, C.M. and SNELL, T.W. Rapid toxicity assessment using ingestion rate of cladocerans and ciliates. Archives of Environmental Contamination and Toxicology, 1994, 28, 508-512.

KAPUSCINSKI, J. DAPI: a DNA-Specific Fluorescent Probe. Journal Biotechnic \& Histochemistry, 1995, 70(5), 220-233. http://dx.doi. org/10.3109/10520299509108199. PMid:8580206.

KCHAOU, N., ELLOUMI, J., DRIRA, Z., HAMZA, A., AYADI, H., BOUAIN, A. and ALEYA, L. Distribution of ciliates in relation to environmental factors along the coastline of the Gulf of Gabes, Tunisia. Estuarine, Coastal and Shelf Science, 2009, 83(4), 414-424. http://dx.doi.org/10.1016/j. ecss.2009.04.019.

KIM, B.M., RHEE, J.S., CHOI, I.Y. and LEE, M.Y. Transcriptional profiling of antioxidant defense system and heat shock protein $\left(H_{s p}\right)$ families in the cadmium- and copper-exposed marine ciliate Euplotes crassus. Genes \& Genomics, 2018, 40(1), 8598. http://dx.doi.org/10.1007/s13258-017-0611-y. PMid:29892903.

KIM, S.H., JUNG, M.Y. and LEE, Y.M. Effect of heavy metals on the antioxidant enzymes in the Marine Ciliate Euplotes crassus. Toxicology, 2011, 3, 213-219.

KIM, S.H., KIM, J.S., LEE, J.S. and LEE, Y.M. Acute effects of heavy metals on the expression of glutathione-related antioxidant genes in the marine ciliate Euplotes crassus. Marine Pollution Bulletin, 2014, 85(2), 455-462. http://dx.doi.org/10.1016/j. marpolbul.2014.05.025. PMid:24882442.

KLEIN, B.N. The "dry" silver method and its proper and use. The Journal of Protozoology, 1958, 5(2), 99- 
103. http://dx.doi.org/10.1111/j.1550-7408.1958. tb02535.x.

KUDO, R.R. Protozoology. Illinois: Charles C. Thomas, 1966, $786 \mathrm{p}$.

LEE, J.J. and SOLDO, A.T. Protocols in protozoology. Lawrence: Society of Protozoologists, 1992, 655 p.

LI, J.I.N.G., MA, X., SU, G., GIESY, J.P., XIAO, Y., ZHOU, B., LETCHER, R.J. and LIU, C. Multigenerational effects of tris(1,3-dichloro2-propyl) phosphate on the free-living ciliate protozoa Tetrahymena thermophila exposed to environmentally relevant concentrations and after subsequente recovery. Environmental Pollution, 2016, 218, 50-58. http://dx.doi.org/10.1016/j. envpol.2016.08.034. PMid:27552037.

LIU, C.B., QU, G.B., CAO, M.X., LIANG, Y., HU, L.G., SHI, J.B., CAI, Y. and JIANG, G.B. Distinct toxicological characteristics and mechanisms of $\mathrm{Hg}^{2+}$ and $\mathrm{MeHg}$ in Tetrahymena under low concentration exposure. Aquatic Toxicology, 2017, 193, 152-159. http://dx.doi.org/10.1016/j.aquatox.2017.10.014. PMid:29096088.

LOMBARDI, J.V. Fundamentos de toxicologia aquática. In: M.J.T. RANZANI-PAIVA, R.M. TAKEMOTO and M.A.P. LIZAMA, eds. Sanidade de organismos aquáticos. São Paulo: Varela, 2004, pp. 263-272.

LYNN, D.H. and SMALL, E.B. An illustred Guide to the Protozoa. In: J.J. LEE, P.C. BRADBURY and G.F. LEEDALE, eds. Phylum Ciliophora. Lawrence, Kansas: Society of Protozoologists, 2002, pp. 371656.

LYNN, D.H. The Ciliated Protozoa: Characterization, classification and guide to the literature. 3rd ed. New York: Springer Press, 2008.

MADONI, P. A sludge biotic index (SBI) for the evaluation of the biological performance of activated sludge plants based on the microfauna analysis. Water Research, 1994, 28(1), 67-75. http://dx.doi. org/10.1016/0043-1354(94)90120-1.

MADONI, P. and BARGHIROLI, S. Changes in the ciliate assemblage along a fluvial system related to physical, chemical and geomorphologic characteristics. European Journal of Protistology, 2007, 43(2), 67-75. http://dx.doi.org/10.1016/j. ejop.2006.09.004. PMid:17222541.

MADONI, P. and ROMEO, M.G. Acute toxicity of heavy metals towards freshwater ciliated protists. Environmental Pollution, 2006, 141(1), 1-7. http://dx.doi.org/10.1016/j.envpol.2005.08.025. PMid:16198032.

MADONI, P. Ciliated protozoans communities and saprobic evaluation of water quality in the hilly zone of some tributaries of the Po River (northern Italy). Hydrobiologia, 2005, 541(1), 55-69. http://dx.doi. org/10.1007/s10750-004-4667-8.
MADONI, P. Protozoa as indicators of wastewater treatment efficiency. In: D. MARA and N. HORAN, eds. The handbook of water and wastewater microbiology. Cambridge: Academic Press, 2003, pp. 361-371. http://dx.doi.org/10.1016/B978012470100-7/50023-6.

MADONI, P. Protozoa in wastewater treatment processes: A minireview. The Italian Journal of Zoology, 2011, 78(1), 3-11. http://dx.doi. org/10.1080/11250000903373797.

MADONI, P. The acute toxicity of nickel to freshwater ciliates. Environmental Pollution, 2000, 109(1), 53-59. http://dx.doi.org/10.1016/S0269-7491(99)00226-2. PMid: 15092912.

MADONI, P., DAVOLI, D., GORBI, G. and VESCOVI, L. Toxic effect of heavy metals on the activated sludge protozoan community. Water Research, 1996, 30(1), 135-141. http://dx.doi.org/10.1016/00431354(95)00124-4.

MADONI, P., ESTEBAN, G. and GORBI, G. Acute toxicity of Cadmium, Copper, Mercury, and Zinc to ciliates from activated sludge plants. Bulletin of Environmental Contamination and Toxicology, 1992, 49(6), 900-905. http://dx.doi.org/10.1007/ BF00203165. PMid:1450572.

MARTÍN-GONZÁLEZ, A., DÍAZ, S., BORNIQUEL, S., GAllego, A. and GUTiÉrrez, J.C. Cytotoxicity and bioaccumulation of heavy metals by ciliated protozoa isolated from urban wastewater treatment plants. Research in Microbiology, 2006, 157(2), 108-118. http://dx.doi.org/10.1016/j. resmic.2005.06.005. PMid:16129584.

MANSANO, A.S., MOREIRA, R.A., PIEROZZI, M., OLIVEIRA, T.M.A., VIEIRA, E.M., ROCHA, O. and REGALI-SELEGHIM, M.H. Effects of diuron and carbofuran pesticides in their pure and commercial forms on Paramecium caudatum: The use of protozoan in ecotoxicology. Environmental Pollution, 2016, 213, 160-172. http://dx.doi. org/10.1016/j.envpol.2015.11.054.

MITCHELL, E.A.D. and MEISTERFELD, R. Taxonomic confusion blurs the debate on cosmopolitanism versus local endemism of free living protists. Protistology, 2005, 156(3), 263-267. http://dx.doi.org/10.1016/j.protis.2005.07.001. PMid:16325540.

MOLDEN, D., FRENKEN, K., BARKER, R., DE FRAITURE, C., MATI, B., SVENDSEN, M., SADOFF, C. and FINLAYSON, C.M. Trends in water and agricultural development. In: D. MOLDEN ed. Water for food, water for life: $A$ comprehensive assessment of water management in agriculture. London, Colombo: Earthscan and International Water Management Institute, 2007.

MÜLLER, H., SCHÖNE, A., PINTO-COELHO, R.M., SCHWEIZER, A. and WEISSE, T. Seasonal succession of ciliates in Lake Constance. Microbial 
Ecology, 1991, 21(1), 119-138. http://dx.doi. org/10.1007/BF02539148. PMid:24194205.

NALECZ-JAWECKI, G., DEMKOWICZDOBRZAHSKI, K. and SAWICKI, J. Protozoan Spirostomum ambiguum as a highly sensitive bioindicator for rapid and easy determination of water quality. The Science of the Total Environment, 1993, 134(2), 1227-1234, Supplement.

NERAD, T.A. and DAGGETT, P.M. Cultivation of selected colorless crypromonads. In: A.T. SOLDO, ed. Protocols of protozoology. Lawrence: Society of Protozoologists, 1992, pp. A71-A73.

NIEMEYER, J.C., MOREIRA-SANTOS, M., NOGUEIRA, M.A., CARVALHO, G.M., RIBEIRO, R., DA SILVA, E.M. and SOUSA, J.P. Environmental risk assessment of a metal contaminated area in the tropics. Tier I: screening phase. Journal of Soils and Sediments, 2010, 10(8), 1557-1571. http://dx.doi. org/10.1007/s11368-010-0255-x.

NISHIGAMI, Y., OHMURA, T., TANIGUCHI, A., NONAKA, S., MANABE, J., ISHIKAWA, T. and ICHIKAWA, M. Influence of cellular shape on sliding behavior of ciliates. Communicative \& Integrative Biology, 2018, 11(4), e1506666. http:// dx.doi.org/10.1080/19420889.2018.1506666. PMid:30534342.

NOLAND, L.E. Factors influencing the distribution of frech water ciliates. Ecology, 1925, 6(4), 437-452. http://dx.doi.org/10.2307/1929108.

OHMURA, T., NISHIGAMIA, Y., TANIGUCHIB, A., NONAKAB, S., MANABEC, J., ISHIKAWAC, T. and ICHIKAWAA, A. Simple mechanosense and response of cilia motion reveal the intrinsic habits of ciliates. Proceedings of the National Academy of Sciences of the United States of America, 2018, 115(13), 32313236. http://dx.doi.org/10.1073/pnas.1718294115. PMid:29531024.

OKI, T. and KANAE, S. Global hydrological cycles and world water resources. Science 313:1068-72 4. Fenwick A. Waterborne infectious diseases-Could they be consigned to history? Science, 2006, 313, 1077-1081.

ORGANIZAÇÃO DAS NAÇÓES UNIDAS UNESCO. The United Nations World Water Development Report 3: Water in a Changing World. Paris/New York: UNESCO/Berghahn Books 2. Huntington TG. 2006. Evidence for intensification of the global water cycle: review and synthesis. Journal of Hydrology, 2009, 319, 83-95.

PAULETO, G.M., VELHO, L.F.M., BUOSI, P.R.B., BRÃO, A.F.S., LANSAC-TÔHA, F.A. and BONECKER, C.C. Spatial and temporal patterns of ciliate species composition (Protozoa: Ciliophora) in the plankton of the Upper Paraná River floodplain. Brazilian Journal of Biology $=$ Revista Brasileira de Biologia, 2009, 69(2), 517-527, Supplement. http://
dx.doi.org/10.1590/S1519-69842009000300007. PMid:19738959.

PRATT, J.R. and CAIRNS JÚNIOR, J. Functional groups in the Protozoa: roles in differing ecosystems. The Journal of Protozoology, 1985, 32(3), 415-422. http://dx.doi.org/10.1111/j.1550-7408.1985. tb04037.x.

PRATT, J.R., MOCHAN, D. and XU, Z. Rapid toxicity estimation using soil ciliates: sensitivity and bioavailability. Bulletin of Environmental Contamination and Toxicology, 1997, 58(3), 387393. http://dx.doi.org/10.1007/s001289900346. PMid:9008047.

PUTTEN, A., KONIG, T., FABRITUS, D., KIY, T., LESKE, A. and PLOTE, J. Method for producing gamma-linolenic acids from a ciliate culture by adding suitable precursor molecules to said culture medium, United States. US20060205047A1. 2006.

PUYTORAC, P. Phylum Ciliophora Doflein, 1901. In: P. PUYTORAC, ed. Traité de zoologie, Tome ii, Infusoires Ciliés, fasc. 2, Systématoque. Masson, Paris: Dunod, 1994, pp. 1-15.

QURESHI, M.E. and HANJRA, M.A. Global water crisis and future security in an era of climate change. Food Policy, 2010, 35(5), 365-377. http://dx.doi. org/10.1016/j.foodpol.2010.05.006.

RAO, J.V., SRIKANTH, K., AREPALLI, S.K. and GUNDA, V.G. Toxic effects of acephate on Paramecium caudatum withspecial emphasis on morphology, behaviour, and generation time. Pesticide Biochemistry and Physiology, 2006, 86(3), 131-137. http://dx.doi.org/10.1016/j.pestbp.2006.02.005.

REHMAN, A., ASHRAF, S., QAZI, J.I. and SHAKOORI, A.R. Uptake of lead by a Ciliate, Stylonychia mytilus, isolated from industrial effluents: Potential use in bioremediation of wastewater. Bulletin of Environmental Contamination and Toxicology, 2005, 75(2), 290-296. http://dx.doi.org/10.1007/s00128005-0751-7. PMid:16222500.

REHMAN, A., SHAKOORI, F.R. and SHAKOORI, A.R. Heavy metal resistant ciliate, Euplotes mutabilis, isolated from industrial effluents can decontaminate wastewater of heavy metals. Bulletin of Environmental Contamination and Toxicology, 2006, 76(6), 907-913. http://dx.doi.org/10.1007/s00128-006-1004-0. PMid:16855894.

REHMAN, A., SHAKOORI, F.R. and SHAKOORI, A.R. Potential use of a ciliate, Vorticella microstoma, surviving in lead containing industrial effluents in waste water treatment. Pakistan Journal of Zoology, 2007a, 39(4), 259-264.

REHMAN, A., SHAKOORI, F.R. and SHAKOORI, A.R. Multiple metal resistance and uptake by a ciliate, Stylonychia mytilus, isolated from industrial effluents and its possible use in wastewater treatment. Bulletin of Environmental Contamination and Toxicology, 
2007b, 79(4), 410-414. http://dx.doi.org/10.1007/ s00128-007-9270-z. PMid:17874022.

REHMAN, A., SHAKOORI, F.R. and SHAKOORI, A.R. Heavy metal resistant freshwater ciliate, Euplotes mutabilis, isolated from industrial effluents has potential to decontaminate wastewater of toxic metals. Bioresource Technology, 2008b, 99(9), 3890-3895. http://dx.doi.org/10.1016/j.biortech.2007.08.007. PMid:17888657.

REHMAN, A., SHAKOORI, F.R. and SHAKOORI, A.R. Uptake of heavy metals by Stylonychia mytilus and its possible use in decontamination industrial wastewater. World Journal of Microbiology \& Biotechnology, 2008a, 24(1), 47-53. http://dx.doi. org/10.1007/s11274-007-9436-1.

REHMAN, A., SHAKOORI, F.R. and SHAKOORI, A.R. Heavy metal uptake by Euplotes mutabilis and its possible use in bioremediation of industrial wastewater. Bulletin of Environmental Contamination and Toxicology, 2009, 83(1), 130-135. http://dx.doi. org/10.1007/s00128-009-9725-5. PMid:19387521.

REHMAN, A., SHAKOORI, F.R. and SHAKOORI, A.R. Multiple heavy metal tolerant ciliates, Oxytricha fallax and Paramecium caudatum, isolated from industrial effluents and their potential use in wastewater treatment. Pakistan Journal of Zoology, 2010a, 42(3), 301-309.

REHMAN, A., SHAKOORI, F.R. and SHAKOORI, A.R. Resistance and uptake of heavy metals by Vorticella microstoma and its potential use in industrial wastewater treatment. Environmental Progress \& Sustainable Energy, 2010b, 29(4), 481-486. http:// dx.doi.org/10.1002/ep.10450.

RICO, D., MARTÍN-GONZÀLEZ, A., DÍAZ, S., LUCAS, P. and GUTIÉRREZ, J.C. Heavy metals generate reactive oxygen species in terrestrial and aquatic ciliated protozoa. Comparative Biochemistry and Physiology. Part C, 2009, 149(1), 90-96. PMid:18725323.

RUTHVEN, J. and CAIRNS JUNIOR, J.J. Response of fresh-water protozoan artificial communities to metals. The Journal of Protozoology, 1973, 20(1), 127 135. http://dx.doi.org/10.1111/j.1550-7408.1973. tb06015.x.

SALVADO, H., GRACIA, M.P., AMIGÓ, J.M. and RIUS, M. Effects of cadmium on growth and Motility in Euplotes aediculatus Isolated from Activated Sludge. Bulletin of Environmental Contamination and Toxicology, 1997, 58(5), 838-844. http://dx.doi. org/10.1007/s001289900410. PMid:9115151.

SCHLENK, D. and MOORE, C.T. Effect of $\mathrm{pH}$ and time on the acute toxicity of copper sulfate to the ciliate protozoan Tetrahymena thermophila. Bulletin of Environmental Contamination and Toxicology, 1994, 53(6), 800-804. http://dx.doi.org/10.1007/ BF00196207. PMid:7881206.
SCHWARZENBACH, R.P., EGLI, T., HOFSTETTER, T.B., VON GUNTEN, U. and WEHRLI, B. Global water pollution and human health. Annual Review of Environment and Resources, 2010, 35(1), 109-136. http://dx.doi.org/10.1146/annurevenviron-100809-125342.

SCHWARZENBACH, R.P., ESCHER, B.I., FENNER, K., HOFSTETTER, T.B., JOHNSON, C.A., VON GUNTEN, U. and WEHRLI, B. The challenge of micropollutants in aquatic systems. Science, 2006, 313(5790), 1072-1077. http://dx.doi.org/10.1126/ science.1127291. PMid:16931750.

SHAKOORI, F.R., ZAFAR, M.F., FATEHULLAH, A., REHMAN, A. and SHAKOORI, A.R. Response of Glutathione Level in a Protozoan Ciliate, Stylonychia mytilus, to Increasing Uptake of and Tolerance to Nickel and Zinc in the Medium. Pakistan Journal of Zoology, 2011, 43(3), 569-574.

SHERR, E.B. and SHERR, B.F. Bacterivory and herbivory: key roles of phagotrophic protists in pelagic food webs. Microbial Ecology, 1994, 28, 223-235.

SILVA, D.C.V.R., POMPÊO, M. and PAIVA, T.C.B. A ecotoxicologia no contexto atual no Brasil. Ecologia de reservatórios e interfaces. São Paulo: Instituto de Biociencias da Universidade de São Paulo, 2015.

SILVEIRA, M.P. Aplicação do biomonitoramento para avaliação da qualidade da água em rios. Jaguariúna: Embrapa Meio Ambiente, 2004, 68 p.

SLABODNICK, M.M., RUBY, G., REIFF, S.B., SWART, C.E., GOSAI, S., PRABAKARAN, S., WITKOWSKA, E., LARUE, G.E., FISHER, S., FREEMAN, R.M., GUWARDENA, J., CHU, W., STOVER, N.A., GREGORY, B.D., NOWACKI, M., DERISI, J., ROY, S.W., WALLACE, F.M. and SOOD, P. The macronuclear genome of Stentor coeruleus reveals tiny introns in a giant cell. Current Biology, 2017, 27(4), R146-R148. http://dx.doi. org/10.1016/j.cub.2016.12.057. PMid:28190732.

SLEIGH, M. Protozoa and other Protists. New York: Chapman and Hall, 1988, 399 p.

SOARES, A.M.V.M. and CALOW, P. Seeking standardization in ecotoxicology. In: A.M.V.M. SOARES and P. CALOW, eds. Progress in standardization of aquatic toxicity test. Boca Raton: Lewis Publishers, 1993.

SOLDO, A.T. and VAN WAGTENDONK, W.J. The nutrition of Paramecium aurelia, stock 299. The Journal of Protozoology, 1969, 16(3), 500-506. http:// dx.doi.org/10.1111/j.1550-7408.1969.tb02307.x. PMid:5343464.

SONNEBOBN, T.M. Methods in Paramecium research. In: D.M. PRESCOTT, Methods in cell physiology. New York: Academic Press, 1970, pp. 241-339.

SWART, E., BRACHT, J.R., MAGRINI, V., MINX, P., CHEN, X., ZHOU, Y., KHURANA, 
J.S., GOLDMAN, A.D., NOWACKI, M., SCHOTANUS, K., JUNG, S., FULTON, R.S., LY, A., MCGRATH, S., HAUB, K., WIGGINS, J.L., STORTON, D., MATESE, J.C., PARSONS, L., CHANG, W.J., BOWEN, M.S., STOVER, N.A., JONES, T.A., EDDY, S.R., HERRICK, G.A., DOAK, T.G., WILSON, R.K., MARDIS, E.R. and LANDWEBER, L.F. The Oxytricha trifallax macronuclear genome: a complex eukaryotic genome with 16,000 tiny chromosomes. PLoS Biology, 2013, 11(1), 1-29. http://dx.doi.org/10.1371/journal.pbio.1001473. PMid:23382650.

TWAGILIMANA, L., BOHATIER, J., GROLIÈRE, C.A., BONNEMOY, F. and SARGOS, D. New lowcost microbiotest with the Protozoan Spirostomum teres: culture conditions and assessment of sensitivity of the ciliate to 14 Pure Chemicals. Ecotoxicology and Environmental Safety, 1998, 41(3), 231244. http://dx.doi.org/10.1006/eesa.1998.1698. PMid:9799574.

UNITED STATES ENVIRONMENTAL PROTECTION AGENCY - US EPA. Methods for Chemical Analysis of Water and Wastes: EPA-600/479- 020. Cincinnati: Environmental Monitoring and Support Laboratory, 1992

USEPA. ECOTOX user guide: ECOTOXicology database system. Version 4.0, 2019 [viewed 28 May 2019]. Available from http:/www.epa.gov/ecotox/.

VELHO, L.F.M., LANSAC-TÔHA, F.M., BUOSI, P.R.B., MEIRA, B.R., CABRAL, A.F. and LANSACTÖHA, F.A. Structure of planktonic ciliates community (Protist, Ciliophora) from an urban lake of southern Brazil. Acta Scientiarum Biological Sciences, 2013, 35(4), 531-539. http://dx.doi. org/10.4025/actascibiolsci.v35i4.18579.

VELHO, L.F.M., PEREIRA, D.G., PAGIORO, T.A., SANTOS, V.D., PERENHA, M.C.Z. and LANSACTÖHA, F.A. Abundance, biomass and size structure of planktonic ciliates in reservoirs with distinct trophic states. Acta Limnologica Brasiliensia, 2005, 17(4), 361-371.

VINDIMIAN, E. The role of ecotoxicology for monitoring ecosystem health. Freshwater Forum, 2001, 16(1), 91-97.
VINOGRADOV, D.V., TSOI, O.V., ZAIKA, A.V., LOBANOV, A.V., TURANOV, A.A., GLADISHEV, V.N. and GEL'FAND, M.S. Draft macronucleus genome of Euplotes crassus ciliate. Molecular Biology, 2012, 46(2), 328-333. http://dx.doi.org/10.1134/ S0026893312020197.

WALKER, C.H., HOPKIN, S.P., SIBLY, R.M. and PEAKALL, D.B. Principles of ecotoxicology. London: Taylor and Francis, 1996.

WANICK, R.C., PAIVA, T.S., CARVALHO, C.N. and SILVA-NETO, I.D. Acute toxicity of cadmium to freshwater ciliate Paramecium bursaria. Biociencias, 2008, 16(2), 104-109.

WEISSE, T. Functional diversity of aquatic ciliates. European Journal of Protistology, 2017, 61(Pt B), 331358. http://dx.doi.org/10.1016/j.ejop.2017.04.001. PMid:28623024.

WU, D., YAN, T., PEI, S., ZHANG, M., WANG, Q., GONG, Z. and CHEN, Y. Inhibitory effect of three heavy mental pollutants on antioxidant enzymes of Paramecium caudatum. Advanced Materials Research, 2015, 1065, 3071-3076.

YOO, J.Y. and HUR, S.B. Evaluation of six species ciliates as a live food and culture enviroment for Euplotes sp. Journal of the Korea Fish Society, 2002, 35, 342-347.

ZHANG, P., XU, J., LU, J., LIANG, A. and WANG, W. Different response of Two metallothionein subfamilies exposed To chromium (vi) in Tetrahymena thermophila. Fresenius Environmental Bulletin, 2013, 22(7), 1924-1928.

ZHANG, X., XIA, P., WANG, P., YANG, J. and BAIRD, D.J. Omics advances in ecotoxicology. Environmental Science \& Technology, 2018, 527(7), 3842-3851. http://dx.doi.org/10.1021/acs.est.7b06494. PMid:29481739.

Received: 23 July 2019 Accepted: 18 March 2020

Associate Editors: André Megali Amado, Joyce Andreia dos Santos, Rafael Marques Almeida, Simone Jaqueline Cardoso. 


\section{Supplementary Material}

Supplementary material accompanies this paper.

Table S1 available at https://cfpub.epa.gov/ecotox/search.cfm.

This material is available as part of the online article from http://www.scielo.br/acta 